O. Horban", orcid.org/0000-0003-2321-5963,

L. Babenko ${ }^{2}$, orcid.org/0000-0002-6828-1414,

I. Lomachinska ${ }^{1}$, orcid.org/0000-0003-2537-6322,

O. Hura ${ }^{2}$, orcid.org/0000-0003-1830-5307, R. Martych $^{1}$, orcid.org/0000-0002-7755-4496

\title{
A KNOWLEDGE MANAGEMENT CULTURE IN THE EUROPEAN HIGHER EDUCATION SYSTEM
}

Purpose. Improving the quality of educational services by identifying the features and current trends in the development of knowledge management culture in the European higher education system.

Methodology. The research methodology involves application of the systematic approach methods. 1. Structural approach related to defining the structural features of knowledge management culture in higher education institutions in Europe. 2. Functional approach that determines the essence and target orientation of the knowledge management function. The use of the comparative method allowed the authors to highlight the essential content of the concept "knowledge management culture" in relation to the concepts of "organizational culture" and "information culture". The dialectical method of cognition was also involved, which made it possible to comprehensively consider the phenomenon of knowledge management culture in educational discourse through the contradictory relationships of its various sides and aspects.

Findings. The culture of knowledge management in the European higher education system is considered at three main levels:

1. Cognitive level, implying a change in the style of thinking, mobilization of intellectual potential, and creativity.

2. Management level, involving the use of analytics and innovative leadership.

3. Technological level, based on the use of information and communication technology in the accumulation, transfer and management of knowledge.

Originality. Knowledge management culture is studied in close relationship with the organizational and information culture. The features of knowledge management at three organizational levels have been determined: cognitive, managerial and technological ones.

Practical value. The institutions of the European higher education system use knowledge to gain and maintain competitive advantages. Insufficient attention to the issue of knowledge management leads to a decrease in the ranking of higher education institutions. The introduction of knowledge management culture provides improvement in the psychological microclimate of a team, dominance of the atmosphere of creativity, an increase in the level of self-education, disclosure of personal intellectual potential, formation of a system of innovative leadership, stimulation of scientific research and, as a result, an increase in the quality of educational services.

Keywords: knowledge management, higher education, university, organizational culture

Introduction. Globalization of modern science requires from the Ukrainian institutions of higher education to improve the quality of scientific research, to introduce interdisciplinary approaches to the creation and dissemination of intellectual resources for active participation in the world scientific space. Actualization of the problem of knowledge management culture is caused by the need to mobilize scientific activity, to practically implement scientific results, and improve the quality of higher education.

The main meanings of the phrase "knowledge management culture", approach to the study on the culture of knowledge management, as well as related meanings of the terms "organizational culture" and "information culture", are promoted by seven key high-quality scientific journals. These are the Leadership \& Organization Development Journal (Scopus, Social Sciences Citation Index (SSCI)) published since 1994; Journal of Knowledge Management (Scopus, Social Sciences Citation Index (SSCI)) published since 1997; Knowledge and Process Management (Scopus, Emerging Sources Citation Index (ESCI)) published since 1997; Journal of Intellectual Capital (Scopus, Social Sciences Citation Index (SSCI)) published since 2000; Knowledge Management Research \& Practice (Scopus, Social Sciences Citation Index (SSCI)) published since 2002; Journal of Information and Knowledge Management (Scopus, Emerging Sources Cita-

(c) Horban O., Babenko L., Lomachinska I., Hura O., Martych R., 2021 tion Index (ESCI)) published since 2002; and International Journal of Knowledge Management (Scopus, Emerging Sources Citation Index (ESCI)) published since 2005.

An analysis of the publications in these journals over the past two years made the authors pay attention to three key areas in organizing knowledge management culture in the modern system of higher education:

1. Studying the nature of knowledge, features of knowledge development, the ability to manage knowledge, information culture, and so on. The authors refer to this line of research as the "cognitive" level.

2. Research on the organizational culture of universities, which provides for the development of effective models of management of higher education institutions and higher education, especially in the context of pandemic. The authors refer to this line of research as the "managerial" level.

3. Investigation of the possibilities of modern information and communication technologies in the accumulation, transfer and management of knowledge. The authors refer to this line of research as the "technological" level.

Consider the features and current trends in the development of knowledge management culture in the European higher education system.

Results. In the study "Implications of total quality management in Ukrainian higher education institutions: international experience", the authors examined the features of the development of higher education institutions in Ukraine in 
comparison with European higher education institutions [1]. In general, the culture of knowledge management in the European higher education system has its own history [2]. It differs from the culture of knowledge management and promoted behaviors in higher education systems in other regions. The main reason for the difference is the complex dynamics of internal movements in Europe associated with the processes of cultural division and integration [3, 4].

Continuous technological and demographic changes, the policy of "open borders", as well as some other reasons are forcing the European higher education system to be flexible and constructive at all three organizational levels of knowledge management: cognitive, managerial and technological ones. We will analyze modern research in this area and identify the main trends in the development of knowledge management culture in the European higher education systems.

Organization of knowledge management culture in the modern system of higher education at the cognitive level. The cognitive level of organizing knowledge management culture provides for the study on the nature of knowledge, the features of knowledge development, the ability to manage knowledge, information culture, and so on. The research at this level involves a change in the style of thinking, mobilization of individual intellectual potential, creativity, transformational leadership, etc.

The cognitive level provides for the conceptualization and formalization of knowledge management culture. B.-S. Tan [5] and I. Lomachinska [6] offered the research tools to investigate the relationship between organizational culture and the performance of knowledge management. Researchers use different approaches; however, they obtain the same result: more homogeneous cultures, which encourage teamwork and have a clearly articulated mission, improve organizational performance and, accordingly, knowledge management $[5,6]$.

Knowledge management models are aimed at conceptualizing and promoting information culture. One of such models is presented in the study by M.S. Reinhardt, et al. [7]. The model demonstrates the possibilities of promoting a specific information culture, energy culture, among students of higher education institutions. The authors propose the use of didactic materials and educational strategies that promote learning and development practice in the context of an efficient and transparent knowledge transfer process, as well as individual practices in behavior change when using energy [7].

The study on innovation and knowledge exchange in the academic literature is of great importance in organizing knowledge management culture in the higher education system. Knowledge exchange in the academic environment is considered to be one of the most important research topics in the field of knowledge management. Knowledge sharing is a major driver of innovation. An organization that encourages knowledge sharing fosters innovative opportunities.

Castaneda D. I. and Cuellar S. found 7991 publications between 1973 and 2017 which deal with innovation and knowledge sharing [8]. Castaneda и Cuellar used the H-index to find the consolidated topics. The consolidated topics in knowledge exchange turned out to be knowledge transfer, knowledge management, and technology transfer. In the case of innovation, they covered the topics of innovation systems, technological innovation, product development, and creativity [8].

Castaneda D. I. and Cuellar S. found that in 2017, the number of published articles on relationships, knowledge sharing and innovations was higher than over the previous years. They concluded that the study on knowledge exchange and innovation moved from a technological approach to knowledge networks at the stage of primary development to knowledge acquisition at the highest stage of development [8]. Castaneda and Cuellar claim that dialogue and collaboration are the main tools for transforming knowledge into innovation. Knowledge is exchanged to foster innovation. This natural focus on dialogue and collaboration explains the collective creation of knowledge and the production of goods and services [8].

Johanson M., Kao P.T., and Lundberg H. investigated the efficiency of knowledge development and knowledge management by way of attracting top professionals and internationalizing an organization [9]. The transfer of three types of knowledge was researched: general knowledge of a foreign market, knowledge of social networks, and professional knowledge. The authors considered both the private and professional connections of the visiting researchers. The research shows that the characteristics of a localized specialist and organization can influence the type of transferred knowledge and the way it is used. The results of the study reveal the key role of a person as a bearer of knowledge and show an alternative way of acquiring knowledge in the context of organization internationalization [9].

The research by M. Johanson, P. T. Kao, and H. Lundberg proves that the internalization of universities is one of the ways to "instill" advanced knowledge in the organization, thereby improving its organizational and information culture. Private and professional contacts of visiting researchers increase the intellectual potential of universities and improve the local information and organizational culture.

Another way to "instill" advanced knowledge in universities was studied by R. N. Pagani, et al. [10]. Their research proves that one of the ways to access advanced knowledge can be (1) international movement of scientists from developing countries, as well as (2) international student mobility as a way to increase tacit knowledge in the country [10]. R. N. Pagani, et al. studied two groups of students, one from Brazil and the other from France, who had been participating in an international student mobility program for more than six months. The results of the study identified the main obstacles and the most effective mechanisms for this category of knowledge and technology transfer. Based on the results obtained, R. N.Pagani, et al. developed a model in which two universities are used as an interface - transmitting and receiving [10].

Cegarra-Navarro J.-G. and Martelo-Landroguez S. draw attention to the problem that is practically not studied in the system of Ukrainian higher education. Namely, the intellectual capital, which is created and developed by the institutions of the higher education system, consists not only of knowledge and practice of its application. The creation of knowledge, its development, and transfer is accompanied by rumors, gossip, inappropriate or false beliefs, delusions, etc., i.e., creating counter-knowledge. The research by J.-G. Cegarra-Navarro and S. Martelo-Landroguez prove that organizational memory not only improves the application of acquired knowledge, but also contributes to the reinforcement of counter-knowledge. Moreover, the research shows that developing organizational memory on the pre-existing link between knowledge and counter-knowledge reduces the flexibility of an organization or "organizational flexibility" [11].

The more knowledge an organization creates, the more counter-knowledge is created. J.-G.Cegarra-Navarro and S. Martelo-Landroguez emphasize that if the influence of counter-knowledge is not promptly reduced, then its accumulation becomes an obstacle to innovation and creativity. The accumulation and consolidation of counter-knowledge lead to a decrease in the effectiveness of an organization in creating knowledge. Cegarra-Navarro and Martelo-Landroguez point out the need to envisage the ways of counteracting the counter-knowledge in modeling knowledge management [11].

Organization of knowledge management culture in the modern system of higher education at the managerial level. The managerial level of organizational and information culture in the European higher education system is guided by two megatrends:

1. Information and communication technologies which are ontinuously becoming more complex.

2. Globalization. 
The current competitive environment is forcing the European higher education system to continuously improve knowledge management models, organizational and information culture. The main feature of universities is the fact that they must not only correspond to modern trends, but also be ahead of them. The university, as a specific organizational structure, must promote an advanced knowledge management culture. It should serve as an example of a new organizational culture, which by its viability, proves the effectiveness of implementing the latest scientific developments in everyday practice.

In our opinion, the experience of leading European universities, which are continuously improving their own organizational and information culture in difficult competitive conditions, is of particular interest for Ukrainian universities. Therefore, a retrospective analysis of the transformational path of a British university towards achieving a new radical mission - to become a "University of Entrepreneurship" - should be seen as an opportunity to rethink the experience of the UK higher education system in order to take the best for its own reform [12].

Purcell W. M. and Chahine T. identified the main idea at the heart of reforming the UK higher education system. Universities are seen as a community of knowledge workers and professionals in providing services in which leadership and management are collegial and consistent. A collegial organization, which is based on conviction and consensus rather than dictate, has the potential for strategic transformation. The collegial organization of universities activates people and unites them around a common goal [12].

Thus, effective reform of the higher education system in the current competitive environment is based on the conscious interaction of leaders with social networks, and is aimed, first of all, at the disclosure and purposeful implementation of the potential of social networks. It is the collegial management model that allows universities to develop and implement advanced organizational and information culture, as well as to carry out global transformations of the organization in an extremely difficult competitive environment [12].

The research by W. M. Purcell and T. Chahine proves the importance of the connection between the command and control structure of the university and the social networks of the staff and stakeholders. This connection is based on the achievement of a common goal - the prospects for university development. Purcell and Chahine conclude that only the organization based on transformational leadership can thrive in a changeable, complex and ambiguous environment and maintain a competitive advantage in a dynamic global market. Leaders who form the backbone of the university command and control structure should be able to use social forces and inspire people to take actions based on a common vision of the university prospect, including the perspectives of these project participants [12].

The conditions of the pandemic have brought about significant changes in the organization of knowledge management culture in the modern system of higher education. The effectiveness of distance teaching and distance organization of higher education has come to the fore. This raised the need to improve the management models of higher education institutions and to change the functions of the key actors in management models. S. Mysirlaki and F. Paraskeva presented the results of studying the influence of emotional intelligence and transformational leadership on the effectiveness of a virtual team [13]. Mysirlaki and Paraskeva focused on three factors: team effectiveness, organizational vitality, and team and organizational satisfaction. The authors found a significant predictive relationship between the perceived emotional intelligence of a leader and the factors of virtual team effectiveness.

The research by S. Mysirlaki and F. Paraskeva justifies the increased dependence of the quality of distance education on transformational leadership. The organization of knowledge management culture in the modern higher education system has come to depend on two key factors:
1. Opportunities for higher education managers to motivate the research and teaching staff.

2. Opportunities for teachers to motivate students.

The research by S. Mysirlaki and F. Paraskeva substantiates a direct relationship between organizational culture and transformational leadership [13].

Communication with production occupies a key place in the organizational culture of modern European education. The main mission of universities is to provide an effective link between knowledge and practice. "University of entrepreneurship" is a new sense of organizational and information culture, on the basis of which the European system of higher education is being reformed.

The relevance and necessity of communication between universities and manufacturing companies is proved by the research of M.van Oostrom, J.A.Pedraza-Rodríguez, and M. Fernández-Esquinas [14]. The authors of the study surveyed 737 companies in the regional innovation system of Andalusia, Spain. The aim of the survey was to prove the importance of the proximity of manufacturing companies to universities and the existence of institutions specializing in the knowledge transfer between universities and companies. The authors concluded that both companies and the engaged institutions located in the Science and Technology Parks are essential in advancing knowledge with local universities. The manufacturing companies, the university and the institutions linking the companies with the university when located in close proximity to each other can ensure the most effective creation of knowledge, its promotion and implementation into production [14].

An important place in modern studies on the managerial level of organizing knowledge management culture is occupied by the studies on "knowledge spillovers effects". G. Barboza and A. Capocchi presented the results of knowledge spillover effects on employment using the database of 245 innovative Italian startups created as a result of adopting the Legislative Decree 179/12 in Italy in 2012 [15]. The empirical results support regional specialization as a major force for knowledge creation and transfer, leading to an increased employment rate. The study by Barboza and Capocchi found that there was a lack of technological convergence between the regions since characteristic regional differences were not overlapped by the knowledge spillover effects [15].

The study by G. Barboza and A. Capocchi demonstrates that regional differences and limited transfer of knowledge between the regions remain the main obstacles to the flow of knowledge [15]. The study suggests that regional universities face the challenge of developing, transferring, and acquiring knowledge. The data support the existing regional heterogeneity in terms of economic and technological specialization as sources of employment.

One way to overcome the knowledge spillover effects faced by regional universities was suggested by M. E. Brown, T. Rizzuto, and P. Singh. Their research reveals the peculiarities of strategic compatibility, cooperation and collective influence of the European higher education system on societal changes [16]. The authors highlight the concept of "strategic compatibility assessment". They suggest using the strategic compatibility assessment (SCA) to identify the inter-organizational potential for collaboration within and between universities as a means of motivating the synergies that are required for societal change initiatives.

Brown M. E., Rizzuto T., and Singh P. argue that the higher education system best solves complex social problems only when solutions are achieved by the joint efforts of higher education institutions. An inter-university partnership is sustainable and efficient when relations between universities are governed by the command and control structure of the Ministry of Education [16].

Brown M.E., Rizzuto T., and Singh P. developed an approach to identifying and forming mutually compatible coop- 
eration between the organizations responsible for sustainable development and prosperity of society. The proposed approach allows improving the higher education governance model based on feedback from the changing European society [16].

Organization of knowledge management culture in the modern system of higher education at the technological level.

The technological level of organization and information culture in the European system of higher education provides for the study on the possibilities of modern information and communication technology in the accumulation, transfer and management of knowledge. Information and communication technologies are seen as a vital part of knowledge management, providing a means for creating, sharing and collecting knowledge.

The research on the relationship between knowledge management and information technology has identified four main directions for the near future. These are social software, consumerization (of knowledge), human factors, and organization of work, systems and practices [17].

Modern realities demonstrate that the efficiency and competitiveness of science and education are ensured not only by human capital, but also by the role of artificial intelligence in the development of human capital.

Vodenko K. V. and Lyausheva S. A. developed the concept of organizing science and education in the form of 4.0 [18]. The proposed concept attracts attention by the fact that, on the one hand, in science and education, the intellectual capital is determined by the decisive factor of production. However, on the other hand, human intelligence does not have to dominate the structure of intellectual capital. The concept claims that artificial intelligence is one of the most popular technologies of the 4.0 Industry in the system of science and education and has broad prospects for practical implementation [18].

The concept of organizing science and education, proposed by Vodenko and Lyausheva, assumes the automation of higher education based on AI by $85 \%$, and for science - by $63 \%$. In general, the authors of the concept argue that the share of artificial intelligence in the structure of intellectual capital can reach $74 \%((85+63) / 2)[18]$.

The research by D. Alassaf, M. Dabić, D. Shifrer, and T. Daim draws attention to the fact that an important place in the organization of knowledge management culture in the modern system of higher education is occupied by open innovations and technologies for their transfer [19]. D. Alassaf, et al. conducted a study "Determination of industrial educational needs in the field of open innovation in Europe" through quantitative analysis using a logistic regression model. The authors surveyed 528 employees across 28 different industries in 37 countries mostly in Europe. The obtained results show that the openness of the organizational and information culture increases the feasibility of adopting the "open innovation" paradigm. It is even of greater importance that the results of the study by D. Alassaf, et al. highlight the positive mediating effects of knowledge and employee rewards on the relationship between open organizations and open innovation [19].

The study by D. Alassaf, et al. explains the reason why cultures of open borders are more likely to have a successful implementation of open innovations and, accordingly, to be more successful in a competitive space [19].

Noteworthy is the study on a new, intensively developing information space, coworking space (CWS). Coworking space (CWS) is a globally growing phenomenon of a new collaborative work environment used by freelancers, entrepreneurs and small businesses that often work in the information technology and creative industries.

The research by A. Rese, C.S. Kopplin, and C. Nielebock discovers the meanings of coworking space (CWS) [20]. A. Rese, et al. studied the exchange of knowledge among colleagues, with a special focus on attitudes, behavior, and individual creativity. The research shows that the attitude towards knowledge sharing and the actual sharing behavior in coworking spaces (CWS) improve the creativity of colleagues and the organization as a whole [20].

Conclusions. Thus, three organizational levels of knowledge management have been researched: cognitive, managerial, and technological ones. The study made it possible to highlight the characteristics of each level and establish the current trends in the development of knowledge management culture in the European higher education system.

The conducted analysis of the leading scientific journals promoting the basic meanings of knowledge management culture allowed the authors to conclude the following:

1. Knowledge management culture in the European higher education system is not limited to the process of knowledge creation, knowledge exchange and knowledge implementation. The European higher education system is faced with the need to solve the problem of the impact of knowledge management culture in individual, group, and organization performance.

2. Knowledge management culture is closely related to the organizational culture of European higher education institutions. The integration processes taking place in the European Union are not likely to overcome regional characteristics. Within the boundaries of the European higher education system, one can observe different dynamics of development and the relationship between organizational and information culture.

\section{References.}

1. Horban, O., Kuprii, T., Martych, R., \& Panasiuk, L. (2020). Implications of total quality management in Ukrainian higher education institutions: international experience. Naukovyi Visnyk Natsionalnoho Hirnychoho Universytetu, (2), 126-130. https://doi.org/10.33271/nvn$\mathrm{gu} / 2020-2 / 126$.

2. Bazaluk, O. (2019). Plato's Traditions in Modern Educational Theories. Annals of the University of Craiova - Philosophy Series, 43(1/2019), 5-20.

3. Boichenko, M. (2020). Intermarium as One of the Future European Image of Ukraine. Future Human Image, 13, 6-13. https://doi. org/10.29202/fhi/13/1

4. Bazaluk, O., \& Balinchenko, S. (2020). Dynamic Coordination of Internal Displacement: Return and Integration Cases in Ukraine and Georgia. Sustainability, 12, 4123. https://doi.org/10.3390/su12104123. 5. Tan, B.-S. (2019). In search of the link between organizational culture and performance: A review from the conclusion validity perspective. Leadership \& Organization Development Journal, 40(3), 356-368. https://doi.org/10.1108/LODJ-06-2018-0238.

6. Lomachinska, I., \& Lomachynsky, B. (2020). The role of information culture in the regulation of social information systems. Visnuk of the Lviv University. Series Philos.-Political Studies, 29, 90-97.

7. Reinhardt, M.S., Ríos, B., Tello, C.P., González Navarro, F., \& Campbell Ramírez, H. (2020). A knowledge management approach to promote an energy culture in higher education. Knowledge Management Research \& Practice, 18(4), 424-438. https://doi.org/10.1080/14 778238.2019.1701962.

8. Castaneda, D. I., \& Cuellar, S. (2020). Knowledge sharing and innovation: A systematic review. Knowledge and Process Management, 27, 159-173. https://doi.org/10.1002/kpm.1637.

9. Johanson, M., Kao, P.T., \& Lundberg, H. (2020). Knowledge grafting during internationalization: utilizing localized professionals in the foreign market. Journal of Knowledge Management, 24(9), 20092033. https://doi.org/10.1108/JKM-12-2018-0747.

10. Pagani, R. N., Ramond, B., Da Silva, V. L., Zammar, G., \& Kovaleski, J. L. (2020). Key factors in university-to-university knowledge and technology transfer on international student mobility. Knowledge Management Research \& Practice, 18(4), 405-423. https://doi.org/10.1 080/14778238.2019.1678415.

11. Cegarra-Navarro, J.-G., \& Martelo-Landroguez, S. (2020). The effect of organizational memory on organizational agility: Testing the role of counter-knowledge and knowledge application. Journal of Intellectual Capital, 21(3), 459-479. https://doi.org/10.1108/JIC-03-2019-0048. 12. Purcell, W. M., \& Chahine, T. (2019). Leadership and governance frameworks driving transformational change in an entrepreneurial UK university. Leadership \& Organization Development Journal, 40(5), 612-623. https://doi.org/10.1108/LODJ-07-2018-0280. 
13. Mysirlaki, S., \& Paraskeva, F. (2020). Emotional intelligence and transformational leadership in virtual teams: lessons from MMOGs. Leadership \& Organization Development Journal, 41(4), 551-566. https://doi.org/10.1108/LODJ-01-2019-0035.

14. van Oostrom, M., Pedraza-Rodríguez, J.A., \& Fernández-Esquinas, M. (2019). Does the Location in a Science and Technology Park Influence University - Industry Relationships?: Evidence From a Peripheral Region. International Journal of Knowledge Management, 15(3), 66-82. https://doi.org/10.4018/IJKM.2019070104.

15. Barboza, G., \& Capocchi, A. (2020). Innovative startups in Italy. Managerial challenges of knowledge spillovers effects on employment generation. Journal of Knowledge Management, 24(10), 2573-2596. https://doi.org/10.1108/JKM-08-2019-0436.

16. Brown, M. E., Rizzuto, T., \& Singh, P. (2019). Strategic compatibility, collaboration and collective impact for community change. Leadership \& Organization Development Journal, 40(4), 421-434. https://doi.org/10.1108/LODJ-05-2018-0180.

17. Sarka, P., Heisig, P., Caldwell, N.H.M., Maier, A. M., \& Ipsen, C. (2019). Future research on information technology in knowledge management. Knowledge and Process Management, 26, 277-296. https://doi.org/10.1002/kpm.1601.

18. Vodenko, K. V., \& Lyausheva, S. A. (2020). Science and education in the form 4.0: public policy and organization based on human and artificial intellectual capital. Journal of Intellectual Capital, 21(4), 549564. https://doi.org/10.1108/JIC-11-2019-0274.

19. Alassaf, D., Dabić, M., Shifrer, D., \& Daim, T. (2020). The impact of open-border organization culture and employees' knowledge, attitudes, and rewards with regards to open innovation: an empirical study. Journal of Knowledge Management, 24(9), 2273-2297. https:// doi.org/10.1108/JKM-02-2020-0122.

20. Rese, A., Kopplin, C.S., \& Nielebock, C. (2020). Factors influencing members' knowledge sharing and creative performance in coworking spaces. Journal of Knowledge Management, 24(9), 2327-2354. https://doi.org/10.1108/JKM-04-2020-0243.

\section{Культура управління знаннями в європейській системі вищої освіти}

\section{О. В. Горбань ${ }^{1}$, Л. Л. Бабенко ${ }^{2}$, I. М. Ломачинська ${ }^{1}$, О.А. Гура ${ }^{2}$, Р. В. Мартич ${ }^{1}$}

1 - Київський університет імені Бориса Грінченка, м. Київ, Україна, e-mail: gorban_oleksandr@ukr.net 2 - Полтавський національний педагогічний університет імені В. Г. Короленка, м. Полтава, Україна

Мета. Підвищення якості освітніх послуг шляхом виявлення особливостей і сучасних тенденцій розвитку культури управління знаннями в європейській системі вищої освіти.
Методика. Методологія дослідження передбачає застосування методів системного підходу. 1. Структурного підходу, пов'язаного з визначенням структурних особливостей культури управління знаннями у вищих навчальних закладах Європи. 2. Функціонального підходу, що визначає сутність і цільову спрямованість функції управління знаннями. Використання порівняльного методу дозволило авторам виділити зміст поняття «культура управління знаннями» у ставленні до понять «організаційна культура» та «інформаційна культура». Також, авторами використовувався діалектичний метод пізнання, що дозволив усебічно розглянути феномен культури управління знаннями в освітньому дискурсі через суперечливість взаємозв'язку різних його сторін і аспектів.

Результати. Культура управління знаннями в європейській системі вищої освіти розглянута на трьох рівнях:

1. Когнітивний рівень, що призводить до зміни стилю мислення, мобілізації інтелектуального потенціалу та креативності.

2. Управлінський рівень, що передбачає застосування аналітики та інноваційного лідерства.

3. Технологічний рівень, заснований на використанні інформаційних і комунікаційних технологій у накопиченні, передачі та управлінні знаннями.

Наукова новизна. Культура управління знаннями досліджена в тісному взаємозв'язку з організаційною та інформаційною культурою. Визначені особливості управління знаннями на трьох організаційних рівнях: когнітивному, управлінському й технологічному.

Практична значимість. Інституції європейської системи вищої освіти використовують знання для отримання й підтримки конкурентних переваг. Недостатня увага питанню управління знаннями призводить до зниження рейтингу вищих навчальних закладів. Упровадження культури управління знаннями забезпечує поліпшення психологічного мікроклімату колективу, домінування атмосфери творчості, підвищення рівня самоосвіти, розкриття особистісного інтелектуального потенціалу, формування системи інноваційного лідерства, стимулювання наукових досліджень і, як результат, - підвищення якості освітніх послуг.

Ключові слова: управління знаннями, вища освіта, університет, організаційна культура

Recommended for publication by O. Brodetskyi, Doctor of Philosophical Sciences. The manuscript was submitted 08.01.21. 